\title{
Transition from Land Use/Cover into Urban Expansion in Dutse Metropolis, Jigawa State, Nigeria
}

\author{
Aminu Sulaiman Zangina ${ }^{1 *}$--- Sabitu Da’u Sa’adu² --- Ahmed Abubakar ${ }^{3}$ \\ ${ }^{\prime}$ Department of Environmental Management, Bayero University, Kano, Nigeria. \\ Email: aminuzangina@gmail.com \\ ${ }^{2}$ Department of Sciences, School for Continuing Education, Bayero University, Kano, Nigeria. \\ ${ }^{s}$ Department of Geography, Sule Lamido University, Kafin Hausa, Jigawa State, Nigeria. \\ Email:abubakar8550483@gmail.com
}

\begin{abstract}
The purpose of this research is to analyse the effect of Urban Expansion on Land Use/Cover Change in Dutse, Jigawa State, Nigeria. Landsat TM and ETM+ satellite imageries of 1986, 2000 and 2014 respectively, were used. The imageries were processed using ERDAS IMAGINE 9.2 software. A supervised classification approach using maximum likelihood classifier and Transition Change Analysis were carried out using IDRISSI 17.O Selva Edition version. Results from the analysis revealed that increase in built-up area resulted to changes in other land use/cover categories between 1986 and 2014. Built up area was 20.4\% in 1986 and increased to 28.4\% in 2000. Further increase was witnessed in built up area to about $38.2 \%$ in 2014. The results further revealed that about $7.2 \%$ bare surfaces changed into built-up from 1986-2014. About 14.8\% of cultivated land changed into built-up from 1986-2014. Vegetation witnessed a remarkable changes into built-up of about 4.5\% from 1986-2014. There is need for Jigawa State Government to equip the planning authorities and other ministries involved in decision making with adequate spatial data to ensure broad based decisions. Land use suitability analysis of the study area is also recommended.
\end{abstract}

Keywords: Land use/land cover, Change detection, Transition, Urban expansion.

Licensed: This work is licensed under a Creative Commons Attribution 4.0 License.

Funding: This study received no specific financial support.

Competing Interests: The authors declare that they have no competing interests.

Acknowledgement: The authors would like to acknowledge the contribution of those involved in the finishing of this article. They would like to thank Abubakar Bio for going through the transition maps.

\section{Introduction}

Virtually everyone stayed in rural areas for several centuries. Only about 3 per cent of the population of the world lived in urban areas of 5,000 or over and many of them seemed like big villages in their activities (socio-economic) by 1800 (United Nations Centre for Housing, Building and Planning, (UNCHBP), 1974). Only about 14 per cent of the world's population lived in urban areas in 1900, and this percentage increased speedily and in the present day over 50 per cent of the populace is living in urban areas (UN, 2010). The world population is estimated to reach about 9.7 billion by year 2050, where about more than half of the increase will occur in Africa, and urban centers will be the focal point of this growth (Addae and Oppelt, 2019). The percentage of people living in urban centers in Africa is projected to reach about $56 \%$ or more by year 2050 (UN DESA, 2017). However, the physical urban areal extent increased substantially due to increase in population as a contributing factor. 
Urbanization is seen to be an important economic and social trend that is happening at a faster rate and scale globally (Sun et al., 2013). The unavoidable outcome of this situation are the spatial increase in extent of urban centers exceeding their official limits, this extend into other land uses or cover to cater for the changes experienced (Mosammam et al., 2017). The uncontrolled urban sprawl has ultimately led to unaccounted negative effects on the populace and their environment (Chadchan and Shankar, 2012).

The development in both extent and numbers of urban areas is referred to as urban expansion (Ifatimehin and Ufuah, 2007). Globally, present day urban expansion is governed by a range of factors which are complex to monitor broadly, which includes land-use policy, international capital flows, generalized costs of transport, and the informal economy (Seto et al., 2011). The most substantial signature of human modification of the environment through varieties of urban land use activities is built up environment, which include, but not restricted to, transportation, residential, industrial, institutional, commercial, and recreational land uses (Ifatimehin and Ufuah, 2007).

Seto et al. (2012) land growth scenarios projection for the year 2030 is based on the three diverse assumptions about the early urban land cover in 2000/2001. Depending on the early extents, the authors' projection of increase in global urban land cover stuck between slightly over 400,000 and much over $1.2,000,000 \mathrm{~km}^{2}$ as of the year 2000 to 2030. Seto et al. (2011) put forward a global urban land area development (expansion) of $58,000 \mathrm{~km}^{2}$ from 1970 to 2000. India, China and Africa have experienced the highest rates of urban land expansion. Global urban land cover is asserted to increase between $430,000 \mathrm{~km}^{2}$ and $12,568,000 \mathrm{~km}^{2}$ by 2030 (Seto et al., 2011). Their average projection scenario shows that urban land will increase from about $600,000 \mathrm{~km}^{2}$ in 2000 to more than $1,250,000 \mathrm{~km}^{2}$ in 2030 and to nearly $2,000,000 \mathrm{~km}^{2}$ in 2050 globally (Angel et al., 2011).

Decline in vegetation resources, escalation of urban congestion, and degradation of the entire ecosystem are some the effects of uncontrolled urban expansion with regards to population and area coverage stressing town planners globally (Ishaya et al., 2008). This is becoming a glaring issue in Western Africa and Nigeria in particular (UNCHS, 1996; Fekede, 2002). Africa is predicted to register the highest increase in urban land cover. The increase will be intense in five regions: the Nile River in Egypt, the coast of West Africa on the Gulf of Guinea, the northern shores of Lake Victoria in Kenya and Uganda, extending into Rwanda and Burundi, the Kano region (Dutse inclusive) in northern Nigeria and greater Addis Ababa, Ethiopia (Seto et al., 2012).

Thematic Committee (2001) asserted that the expansion of human settlements has been phenomenal in Nigeria. Less than 15 percent of the population of Nigeria lived in urban areas in 1950, rising to 23.4 percent in 1975 , and 43.5 percent in year 2000 respectively, and it has been projected to be over 50 percent by the year 2010. This has led to accelerated expansion of cities at the expense of ecological resources such as vegetation, agricultural land and water resources. Nigerian cities are expanding at a regular rate of $5.8 \%$ per annum (Obinna et al., 2010).

Application of geospatial techniques in LULC change has been enormous and has been happening for a long time (Dewan et al., 2012; Sun et al., 2016; Bhat et al., 2017). The increased expansion of urban areas at the expense of other LULC are unprecedented and has led to (Dewan et al., 2012; Liu et al., 2014), farm displacement (Du et al., 2013) leading to arable land loss and habitat destruction (Bhat et al., 2017).

\section{Materials and Methods}

\subsection{The Study Area}

Dutse town is the Administrative Headquarters of Jigawa State created on Tuesday 27, August, 1991 from the old Kano State.

\subsection{Location and Extent}

Dutse is located between Latitudes $11^{\circ} 38^{\prime} 31^{\prime \prime} \mathrm{N}$ and $11^{\circ} 46^{\prime} 16^{\prime \prime} \mathrm{N}$ and longitudes $9^{\circ} 18^{\prime} 33^{\prime \prime} \mathrm{E}$ and 9 $24^{\prime} 24^{\prime \prime} \mathrm{E}$. Dutse Local Government Area is bordered by Ringim and Jahun Local Government Area to the North, Birnin Kudu Local Government Area to the South, Kiyawa and Gaya Local Government Areas to the East and West respectively (Aliyu, 2005) see Figure 1. 


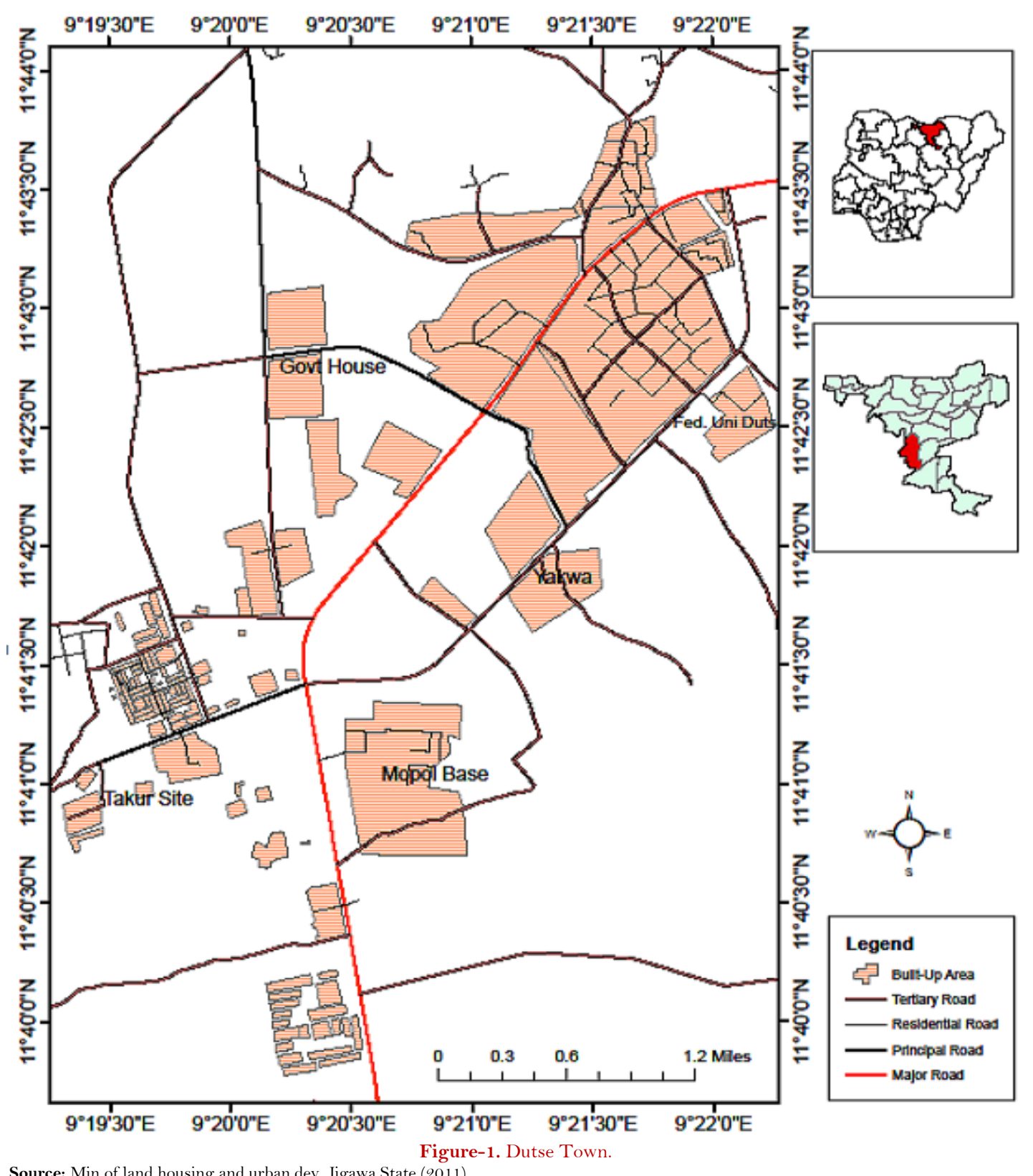

2.2. Nature and Sources of Data

The Landsat imageries used for this research were of 1986, 2000, and 2014, obtained from GLCF. The study area lies on path 188 Row 52 on world referencing system. The primary data used were: Landsat TM of 1986 with 30m spatial resolution, Landsat ETM $^{+}$of 2000 and 2014 with band 1-7 having 30m resolution while band 8 which is panchromatic having $15 \mathrm{~m}$ resolution. The documentary sources of data include: journals, thesis, projects, and other relevant secondary documents.

\subsection{Method of Data Analysis}

The satellite images were digitally processed within; they were ortho-rectified as such there was no need for any geometric and radiometric corrections. The images were obtained in different layers and the layers were stacked together using ERDAS imagine 9.2 software; A subset of the study area was obtained using the ERDAS imagine software subset tool. However, the images were geo-referenced using ERDAS imagine 9.2 software geo-referencing tool.

The analysis was done with IDRISI for windows 17.1 Selva edition software in determining the transition that has taken place from land use land cover changes into urban expansion. The extent to which urban expansion influences land use/land cover changes in the area was determined by Land Change Modeller (LCM) change analysis through transition map which shows all the transition that is, the change and spatial trend from all other land use/cover into built-up between classified imageries of 1986-2000, 2000-2014 and 1986-2014, and identified how much urban land has increased over the years at the expense of other land use/land cover during the study period (see Figure 2 for a flow chart of the study). 


\subsection{Digital Image Classification}

IDRISI 17.1 Selva Edition software was used for the pixel-based classification. Supervised classification was performed using maximum likelihood classifier since it is a land use/land cover classification which produced the output raster layer. The three images were classified into different land cover types. Maximum likelihood algorithm was used to classify the images and the digital numbers of the pixels were grouped with pixels arranged and organized into land cover classes of built-up area, vegetation, bare surface, rock outcrops, cultivated land and water bodies (see Table 1 for land use/cover classification scheme).

\subsection{Software and Hardware}

The satellite imageries were digitally analyzed using ERDAS IMAGINE 9.2 software and IDRISI 17.1 Selva Edition software for the purpose of extracting more information about the study area on changes that have occurred over the period of time under focus. The classified maps were imported into IDRISI 17.1 software for transition map analysis. The Hardware used in this study includes; a printer, scanner, and a system.

Table-1. Land use/ land cover classification scheme.

\begin{tabular}{l|l}
\hline Classes & Description \\
\hline Built-up & Residential, commercial, industrial, villages \\
\hline Bare soil/landfill & Exposed soils, landfill, and areas of active excavation and production \\
\hline Cultivated land & Cleared forest lands and deforested area, farm lands \\
\hline Vegetation & Any species of plants (flora), forest \\
\hline Water bodies & River, lakes and reservoirs \\
\hline Rock outcrops & Any type of rock identified \\
\hline Source: Jensen (2005).
\end{tabular}

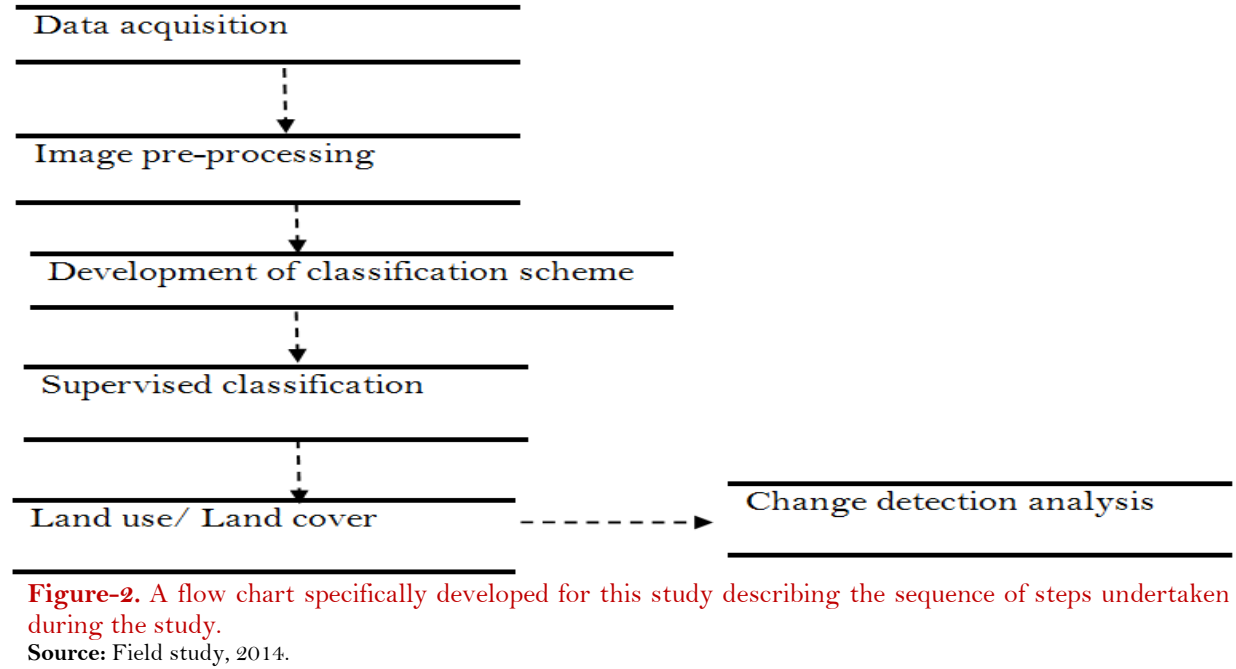

\section{Results and Discussion}

3.1. Transition from Land Use/Cover into Built-Up

This is one of the unique capabilities of IDRISI 17.1 Selva Edition of analyzing the transition that takes place from land use/cover into built-up within the study period. This will go a long way in showing the extent to which urban expansion influences other land use/cover within the study period. Table 2 shows the tabulated transition from other land use/cover coverage into built-up from 1986 to 2014.

Table-2. Transition from land use/cover into built-up area of Dutse Town between 1986-2000, 2000-2014 and 1986-2014.

\begin{tabular}{c|c|c|c|c|c|c}
\hline \multirow{2}{*}{$\begin{array}{c}\text { Land use/cover } \\
\text { categories }\end{array}$} & \multicolumn{2}{|c|}{$\mathbf{1 9 8 6 - 2 0 0 0}$} & \multicolumn{2}{c|}{$\mathbf{2 0 0 0 - 2 0 1 4}$} & \multicolumn{2}{c}{$\mathbf{1 9 8 6 - 2 0 1 4}$} \\
\cline { 2 - 7 } & $\begin{array}{c}\text { Areas in } \\
\text { hectares }\end{array}$ & $\mathbf{\%}$ & $\begin{array}{c}\text { Areas in } \\
\text { hectares }\end{array}$ & \% & $\begin{array}{c}\text { Areas in } \\
\text { hectares }\end{array}$ & \% \\
\hline No data & 7292.41 & 86.9 & 7117.53 & 84.8 & 6049.06 & 72.0 \\
Bare/S & 273.06 & 3.3 & 364.00 & 4.3 & 601.66 & 7.2 \\
Cultivated/L & 591.30 & 7.0 & 653.58 & 7.8 & 1244.88 & 14.8 \\
Rock/O & 58.50 & 0.7 & 57.63 & 0.7 & 116.13 & 1.4 \\
Vegetation & 178.78 & 2.1 & 202.14 & 2.4 & 380.92 & 4.5 \\
Water/B & 2.23 & 0.0 & 1.40 & 0.0 & 3.63 & 0.1 \\
\hline Total & 8396.28 & 100.00 & 8396.28 & 100.00 & 8396.28 & 100.00 \\
\hline Source: Author's GIS analysis, 2014.
\end{tabular}




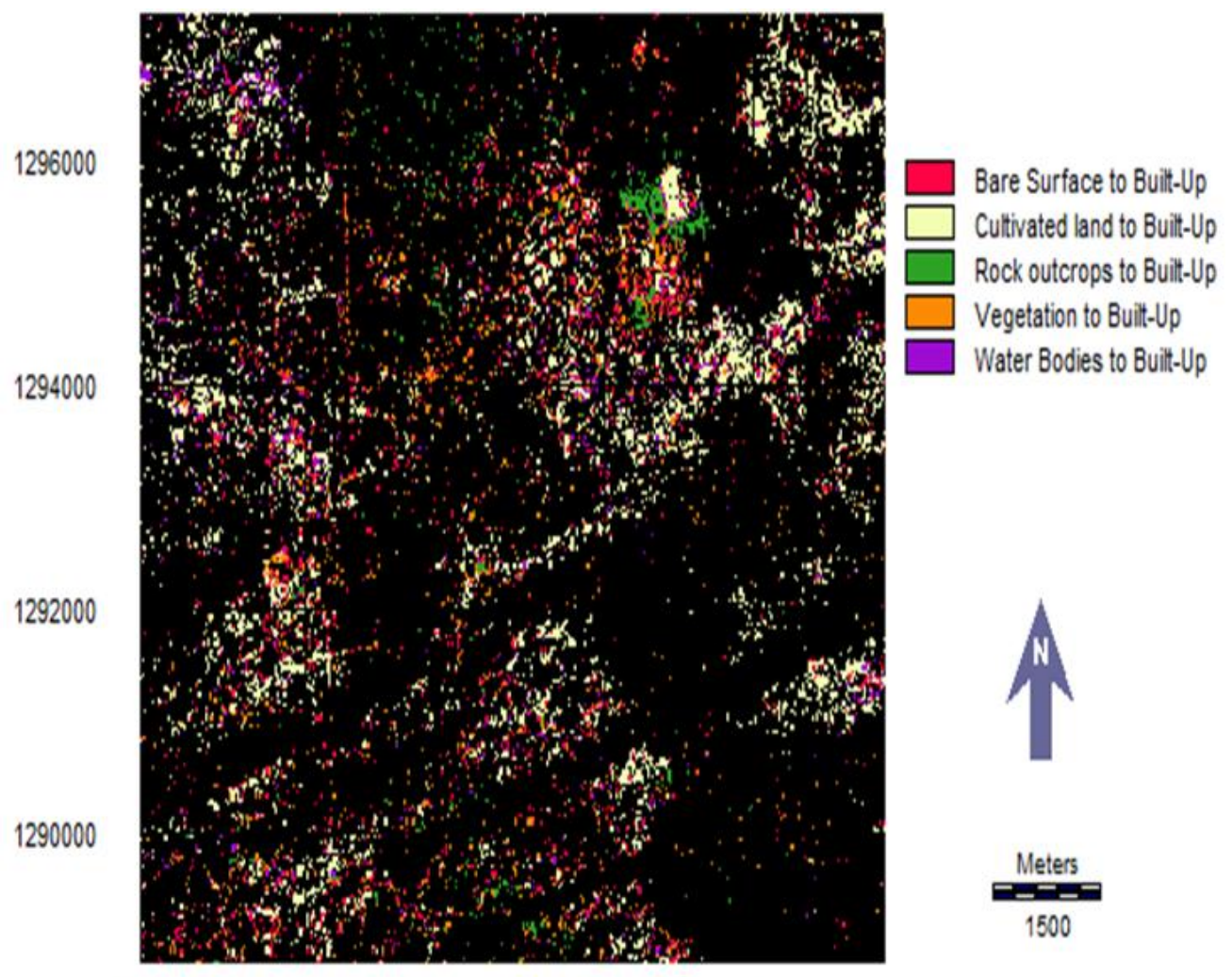

\section{$534000 \quad 536000 \quad 538000 \quad 540000 \quad 542000$}

Figure-3. Transition from classified land use/Cover map to built-up of Dutse Town for 1986-2000. Source: Author's GIS analysis, 2014

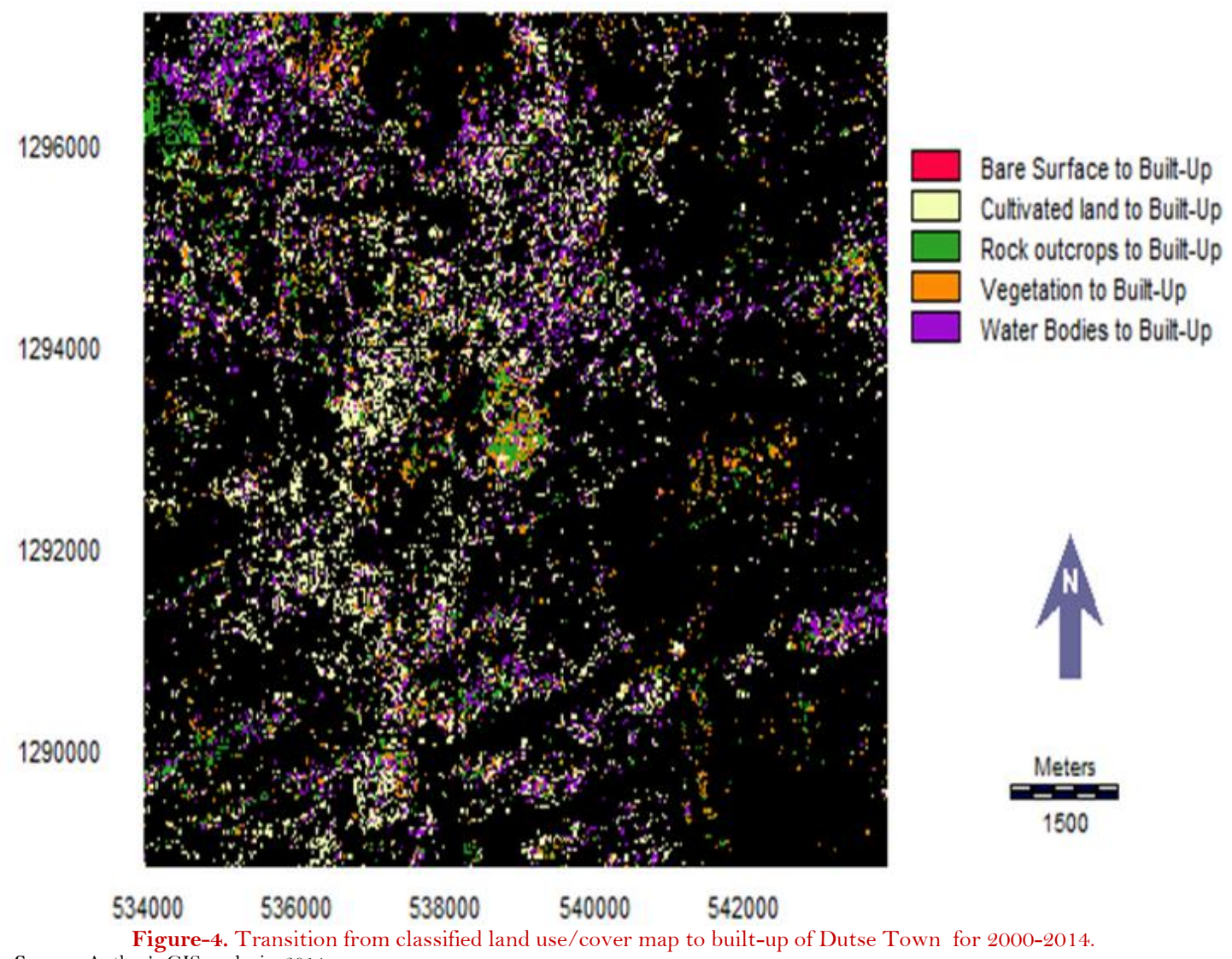
Source: Author's GIS analysis, 2014. 


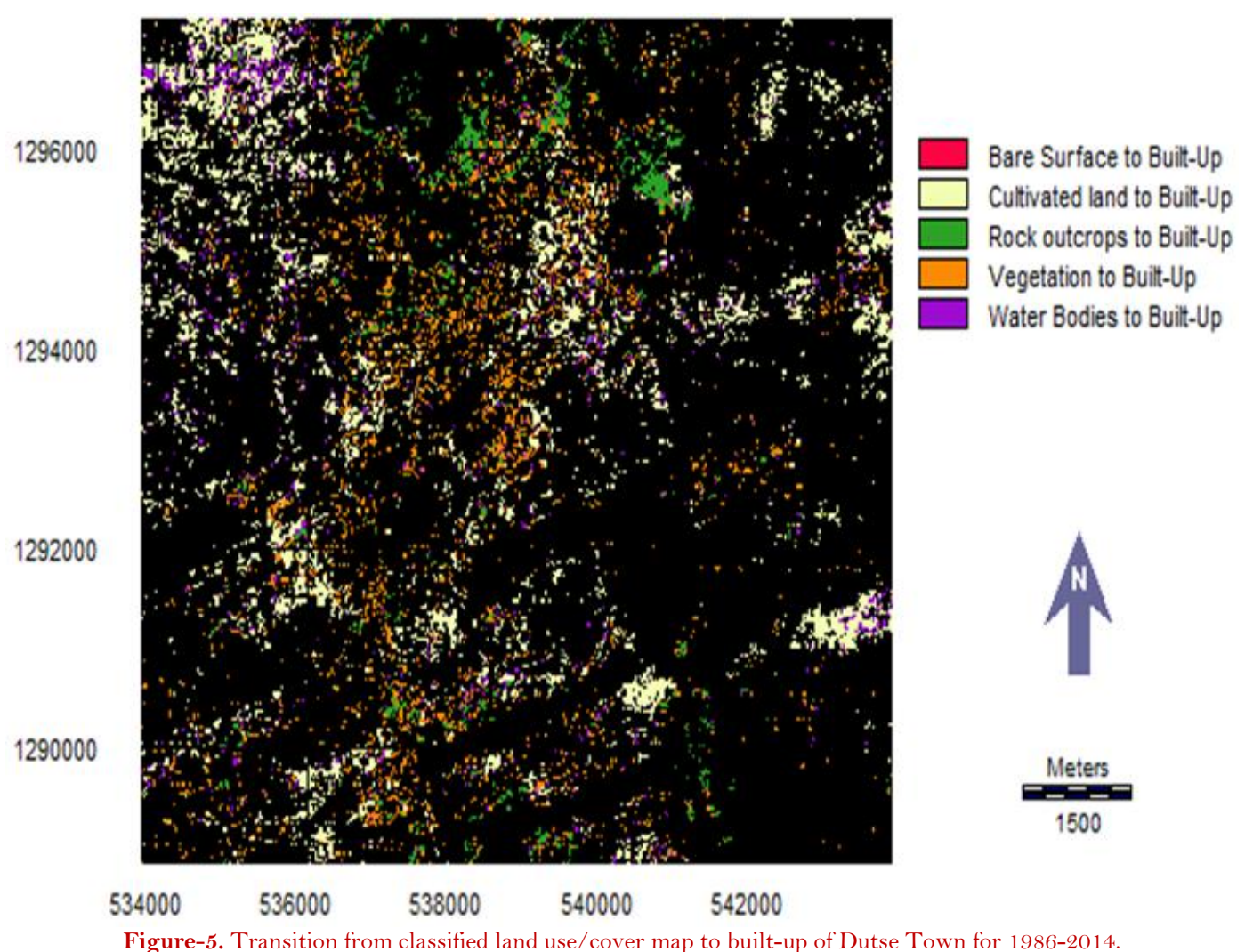

Source: Author's GIS analysis, 2014.

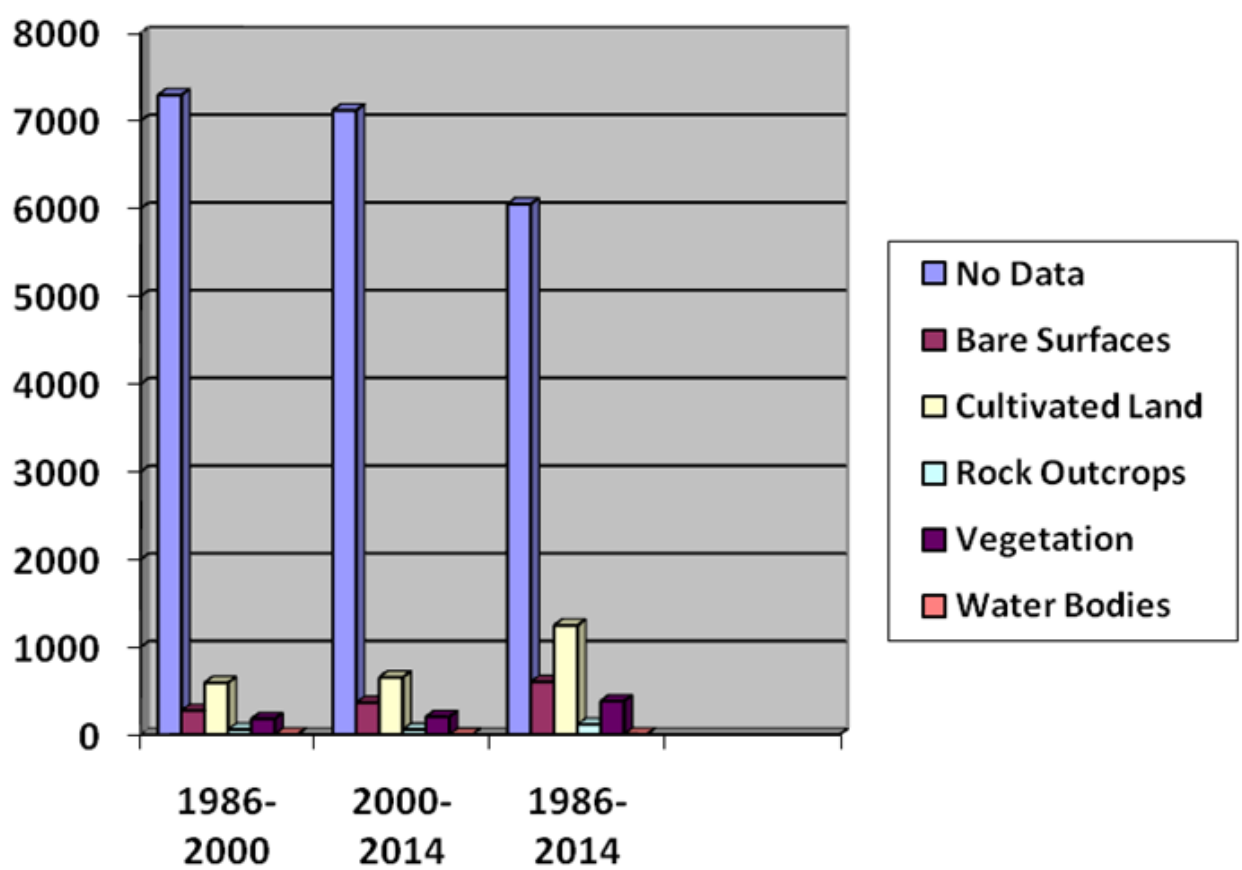

Figure-6. Bar chart of transition from land use/cover change to built-up from 1986 to 2014 Source: Author's GIS analysis, 2014.

It is seen from the foregoing results obtained as shown in the transition maps that other land use/cover classes changed into built-up which led to urban expansion experienced within the study period. It is asserted that bare surfaces changed into built-up of about 273.06 hectares from 1986-2000 (see Table 2, Figure 5, and Figure 6), 364.00 hectares from 2000-2014 (see Table 2, Figure 4, and Figure 6), and 601 hectares from 19862014 (see Table 2, Figure 5, and Figure 6), this is one of the reasons why bare surfaces have been fluctuating over the span of the study period which led to its reduction at the expense of urban expansion.

Cultivated land as obtained from the result shows that about 591.30 hectares (7.0\%) from 1986-2000 (see Table 2, Figure 5, and Figure 6), 653.58 hectares (7.8\%) from 2000-2014 (see Table 2, Figure 4, and Figure 6), and 1244.88 hectares (14.8\%) from 1986-2014 (see Table 2, Figure 5, and Figure 6) changed into built-up and 
this might be attributed to the fact that urban expansion was experienced within the study period at the expense of the cultivated land. This led to the reduction in cultivated land except in year 2000 that a slight increase was experienced due to the time the imagery was obtained and the economic activity engaged by the people of the area.

Rock outcrops changed into built-up of about 58.50 hectares (0.7\%), 57.63 hectares (0.7\%) and 116.13 hectares (1.4\%) from 1986-2000, 2000-2014 and 1986-2014 respectively (see Table 2, Figure 3, Figure 4 Figure 5, and Figure 6). This is due to the fact that quarrying for urban expansion was taking place in the area and the effect of weathering might have taken its cause within the study period. Though, the decrease experienced is minimal which solely represent urban expansion that is taken place at the expense of rock outcrops in the study area.

As revealed by the results obtained from the analysis vegetation changed into built-up of about 178.78 hectares, 202.14 hectares and 380.92 hectares from 1986-2000, 2000-2014 and 1986-2014 respectively (see Table 2, Figure 3, Figure 4, Figure 5, and Figure 6). This is attributed to the fact that vegetation is cleared due to urban expansion for developmental purposes and it also affirms the fact that vegetation is decreasing throughout the study period at the expense of built-up areas.

The transition maps revealed that water bodies of about 2.23 hectares (0.0\%) from 1986-2000, 1.40 hectares (0.0\%) and 3.63 hectares (0.1\%) from 2000-2014 and 1986-2014 changed into built-up respectively (see Table 2, Figure 3, Figure 4, Figure 5, and Figure 6). This is minimal because of the fact that it's unlikely for a substantial amount of water bodies to change into built-up but rather into bare surfaces when it dries up, cultivated land or vegetation as confirmed by the results.

Based on the foregoing results and discussion it is very clear that the extent to which urban expansion influences land use/cover in the study area have been known and established using geospatial analysis.

\section{Conclusion}

The use of geospatial analysis in this study revealed an increase in built up areas due to continuous expansion, construction work and urbanization of the area as a result of the creation of Jigawa State in 1991. The study has shown the extent at which other land use land cover changes are been transformed into built up which is an indication of urban expansion with its serious unforeseen consequences which need to be addressed.

This has imposed significant pressure on the environment and natural resources with serious implications on spatial organization within the area. The search for a way forward will therefore require a synthesis of present situation and the identification of options for feasible intervention. This will serve as an eye opener and will also help in policy formulation of Dutse urban center with regards to its land uses and land cover. The study serves as a guiding document for government, urban planners, and private organizations in their future policy framework.

\section{Recommendations}

1. More studies can be conducted in the study area using satellite imageries with higher spatial resolution.

2. Land use suitability analysis of the study area is also recommended.

\section{References}

Addae, B. \& Oppelt, N. (2019). Land-use/land-cover change analysis and urban growth modelling in the greater accra metropolitan area (GAMA), Ghana. Urban Science, 3(1): 3-26. Available at: $10.3390 /$ urbansci3010026.

Aliyu, M.A. (2005). Assessment of land use changes in Dutse Town using remote sensing application. Unpublished B. Sc Project, Department of Geography, Bayero Universty, Kano.

Angel, S., Parent, J., Civco, D. L., Blei, A. \& Potere, D. (2011). The dimensions of global urban expansion: Estimates and projections for all countries, 2000-2050. Progress in Planning, 75(2): 53-107.

Bhat, P. A., Ul Shafiq, M., Mir, A. A. \& Ahmed, P. (2017). Urban sprawl and its impact on landuse/land cover dynamics of Dehradun City, India. International Journal of Sustainable Built Environment, 6(2): 513521.

Chadchan, J. \& Shankar, R. (2012). An analysis of urban growth trends in the post-economic reforms period in India. International Journal of Sustainable Built Environment, 1(1): 36-49.

Dewan, A.M., Yamaguchi, Y. \& Rahman, M.Z. (2012). Dynamics of land use/cover changes and the analysis of landscape fragmentation in Dhaka Metropolitan. Bangladesh Geojournal, 77(3): 315-330.

Du, S., Shi, P. \& Rompaey, A.V. (2013). The relationship between urban sprawl and farmland displacement in the Pearl River Delta. China Land, 3(34): 34-51.

Fekede, W. (2002). Deficits in urban land management and informal responses under rapid urban growth, an international perspective. Habitat International, 24(2): 127-50.

Ifatimehin, O.O. \& M.E. Ufuah, (2007). An analysis of urban expansion and loss of vegetation cover in Lokoja, using GIS techniques. Zaria Geographer. Journal of Environmental Studies and Human Development, 17(1): 28-36. 
Ishaya S., Ifatimehin, O.O. \& Okafor, C. (2008). Remote sensing and GIS applications in urban expansion and loss of vegetation cover in Kaduna Town, Northern Nigeria. American-Eurasian Journal of Sustainable Agriculture, 2(2): 117-124.

Jensen, J. R. (2005). Introductory digital image processing: A remote sensing perspective. 3rd Edn., Bergen (NJ): Pearson Prentice Hall.

Liu, Y., Chen, J., Cheng, W., Sun, C., Zhao, S. \& Pu, Y. (2014). Spatiotemporal dynamics of the urban sprawl in a typical urban agglomeration: A case study on Southern Jiangsu, China (1983-2007). Frontiers in Earth Science, 8(4): 490-504.

Mosammam, H. M., Nia, J. T., Khani, H., Teymouri, A. \& Kazemi, M. (2017). Monitoring land use change and measuring urban sprawl based on its spatial forms: The case of Qom city. The Egyptian Journal of Remote Sensing and Space Sciences, 20(1): 103-116. Available at: http://doi.org/10.1016/j.ejrs.2016.08.002.

Obinna, V. C., Owei, O. B. \& Mark, E. O. (2010). Informal settlements of Port Harcourt and potentials for planned city expansion. Environmental Research Journal, 4(3): 222-228.

Seto, K. C., Fragkias, M., Güneralp, B. \& Reilly, M. K. (2011). A meta-analysis of global urban land expansion. PloS One, 6(8): e23777. Available at: 10.1371/journal 002377.

Seto, K. C., Güneralpa, B. \& Hutyra, L.R. (2012). Global forecasts of urban expansion to 2030 and direct impacts on biodiversity and carbon pools. Proceedings of the National Academy of Sciences of the United States of America, 109(40): 16083-16088.

Sun, C., Wu, Z. F., Lv, Z. Q., Yao, N. \& Wei, J. B. (2013). Quantifying different types of urban growth and the change dynamic in Guangzhou using multi-temporal remote sensing data. International Journal of Applied Earth Observation and Geoinformation, 21: 409-417.

Sun, L., Wei, J., Duan, D. H., Guo, Y. M., Yang, D. X., Jia, C. \& Mi, X. T. (2016). Impact of land-use and landcover change on urban air quality in representative cities of China. Journal of Atmospheric and SolarTerrestrial Physics, 142: 43-54.

Thematic Committee, (2001). Sustainable Urban Development and Good Governance in Nigeria - Istanbul.

United Nations, (2010). World urbanization prospects: The 2009 revision. Population Division of the Department of Economic and Social Affairs, United Nations, New York.

United Nations, Department of Economic and Social Affairs/Population Division, (2017). World population prospects: The 2017 revision, key findings and advance tables. ESA/P/WP/248; United Nations: New York, NY, USA.

UNCHBP- Centre for Housing Building and Planning, (1974). Human settlements: The environmental challenge. London: Macmillan.

UNCHS-United Nations Center for Human Settlements, (1996). An urbanizing world: World global report on human settlements. New York: Oxford University Press. 